\title{
A DECADE OF BALANCING WITH EU HUMAN RIGHTS PROTECTION: BETWEEN NATIONAL AND INTERNATIONAL COMPETENCES AND SOURCES OF LAW, INDIVIDUAL AND SYSTEMIC INTERESTS
}

\author{
Maja Lukić, PhD, Associate Professor \\ University of Belgrade, Faculty of Law \\ Bulevar Kralja Aleksandra 67, Beograd \\ maja.lukic@ius.bg.ac.rs
}

\author{
Bojana Čučković, PhD, Associate Professor \\ University of Belgrade, Faculty of Law \\ Bulevar Kralja Aleksandra 67, Beograd \\ cuckovic@ius.bg.ac.rs
}

\begin{abstract}
The path towards establishing and advancing human rights' protection within the EU legal system seemed straightforward a decade ago. With the entry into force of the Lisbon Treaty in 2009, the Charter of Fundamental Rights of the EU became part of primary law, together with a commitment of accession to the European Convention on Human Rights. In 2010, Protocol 14 to the ECHR entered into force, allowing the EU to accede to the ECHR. A draft agreement on accession was finalized thereafter. In 2014, however, the Court of Justice of the European Union issued a negative opinion on the draft accession treaty, citing perceived threats to autonomy of EU law, competence of the EU and powers of the Court. A year earlier, in February 2013, the CJEU rendered judgments in cases Fransson and Melloni whereby it provided crucial rules for interpretation of clauses 51(1) and 53, respectively, of the Charter. The field of application of the Charter was equated with the scope of EU law. Primacy, effectiveness and unity of EU law, both primary and secondary, were prioritized over human rights and fundamental freedoms recognized by international agreements, including the ECHR, as well as by the Member States' constitutions. The realm of fundamental individual rights remains to this day the decisive grounds for asserting the core principle of EU constitutionality: the autonomy of EU law. Accession to the ECHR remains to this day a proclaimed goal of EU governing bodies, but little palpable progress is being made. Protection of fundamental rights at EU level has remained a point of contention among academics. Some question the very need for its existence, in view of constitutional guarantees by Member States and the ECHR.
\end{abstract}


Others, however, claim that the CJEU sacrificed protection of individuals' rights for the interest of promoting constitutionality of the EU. These critiques seem unwarranted. Article 2 TEU necessitates existence of an efficient mechanism for protection of fundamental freedoms at EU level. Historical examples of political communities built on multi-ethnic, civic model all show necessity of integrating human rights protection at the constitutional level. Constitutionality of the EU has been developing for six decades, for the most part under the guise of autonomy of EU law. It requires that primacy of fundamental rights, as guaranteed by EU law, be affirmed both vis-à-vis Member States and international treaties. However, one may not expect that fundamental rights and freedoms within the EU be protected in a uniform and efficient manner unless a system for enforcing such rights and freedoms is not put in place first.

Keywords: EU Charter of Fundamental Rights, Kadi, Melloni, Fransson, primacy of EU law, constitutionality of EU law, Tarrico

\section{INTRODUCTORY REMARKS}

The turn of the first decade of the $21^{\text {st }}$ century seemed to have put the protection of human rights within EU law on a firm and transparent footing. With the entry into force of the Lisbon Treaty on 1 December 2009, the Charter of Fundamental Rights of the European Union (the Charter) became part of primary law, together with a commitment of accession of the EU to the European Convention for the Protection of Human Rights and Fundamental Freedoms (ECHR). In 2010, Protocol 14 to the ECHR entered into force, allowing the EU to accede to the ECHR. This ultimately led to the finalization of the draft agreement on EU accession to the ECHR in April 2013. The newly formed normative framework did not seem conducive to creating contentious issues.

In contrast to such semblance, however, the past decade brought about several major developments of contentious nature in the realm of EU law on human rights. Naturally, a question arises on whether a sensible development, or a regression may be discerned in the outcomes of subject conflicts, or the conflicts have played out in a random and chaotic fashion. In order to be able to look for an answer to that question, however, one needs to identify a perspective on the context of the subject phenomena.

The issues that were raised had a common root: plurality of layers of human rights protection in EU law, both in terms of sources of law - national constitutions, the Charter, the ECHR etc - and in terms of courts competent for enforsing said sources - ordinary and constitutional courts of Member States, the Court of Justice of the European Union (CJEU, or Court), the European Court of Human Rights (ECtHR)

It seems that the subject developments should be analyzed in the context of the process of constitutionalization of the EU, i.e. that the substance of the inquiry 
should consist in learning whether said developments furthered that process, reversed it to a certain extent, or have not had any impact upon it.

The reasons for such choice of context are manifold. The subject matter of human rights protection firmly belongs to the universally accepted realm of materia constitutionis. The process of constitutionalization of the European Communities by virtue of case law of the CJEU spans five decades, between its Costa v. Enel and Kadi judgments. The creative role of the CJEU in respect of constitutionalization of EU law has been established in academic literature for several decades. ${ }^{1}$ Case law of the CJEU also represents the primary environment in which the conflicts that are the subject of this paper have transpired. ${ }^{2}$ Last but not least, in view of the conceptual proclamation of the "ever closer Union", a finding on whether the Union has in fact become closer as result of the subject developments is certainly warranted.

It should be noted that although the subject conflicts have both played out in the framework of, and resolved by virtue of case law of the CJEU, their outcomes, due to the formative role of the CJEU, have a profound impact not only on EU law, but also on the values and policies of the EU. These judgments have provoked a great deal of discussions and many opposing views among academics, as well as in the realms of law and public policy, so that they may be regarded as embodiments of wide intellectual, societal and political disputes. Their holdings have a capability to influence the manner in which EU law, its values and its constitutionality are conceptualized in the future. These are precisely the reasons why we use a reference to contentious developments in the area of human rights law, instead simply to judgments of the CJEU.

Weiler, J.H.H, The Reformation of European Constitutionalism, Journal of Common Market Studies, vol. 35, issue No. 1, 1997, p. 98

2 In fact, protection of fundamental rights under Community and Union law was born and had developed until the drafting and enactment of the Charter not by virtue of the founding treaties, but by virtue of case law of the CJEU, which regarded fundamental rights as an integral part of general principles of Community law. Trstenjak, V.; Beysen, E., The Growing Overlap of Fundamental Freedoms and Fundamental Rights in the Case Law of the CJEU, European Law Review, vol. 38, no. 3, 2013, p. 294; Opinion of the Court 2/13 of 18 December 2014, [2014] ECR, ECLI:EU:C:2014:2454, par. 37 


\section{MELLONI - NATIONAL CONSTITUTIONAL RIGHTS V. EU LAW}

\subsection{The facts of the case and the holding}

In February 2013 the CJEU issued a judgment in the case Stefano Melloni v. Ministerio Fiscal, ${ }^{3}$ thereby ceasing the opportunity to add an important tenet to the doctrine of primacy of EU law. It did so in response to the first ever request for a preliminary ruling made by the Spanish Constitutional Court.

The reference for a preliminary ruling was made in relation to interpretation of the right to a fair trial, as guaranteed by Article 47 of the Charter and by the Spanish Constitution. The Spanish Constitutional Court had been interpreting Spanish Constitution as requiring that a person tried in absentia had to be afforded right to apply for a retrial, irrespective of whether such person had been represented by lawyers in the first trial. Contrary to such interpretative rule, a framework decision of the Council of $2009^{4}$ amending, inter alia, the basic framework decision on the European Arrest Warrant of 2002, ${ }^{5}$ explicitly excluded the possibility that the judicial authority executing the European Arrest Warrant (EAW) may refuse to execute such a warrant issued for the purpose of executing a custodial sentence or a detention order if the subject person, even though he or she did not appear in person at the trial, inter alia, "had given mandate to a legal counsellor... to defend him or her at the trial, and was indeed defended by that counsellor at the trial." ${ }^{6}$

In the case at hand, Stefano Melloni, although not present in person, was undisputedly represented by lawyers at a trial before Bologna Appeal Court in 2003, at which he was sentenced to ten years in prison for bankruptcy fraud. ${ }^{7}$ After he was arrested in Spain in 2008, proceedings for his surrender to Italy pursuant to EAW were commenced. Mr. Melloni eventually petitioned to the Spanish Constitutional Court, claiming, inter alia, that his right to a fair trial would be violated by

3 Judgment of 26 February 2013, Stefano Melloni v. Ministerio Fiscal, C-399/11, [2013] ECR, ECLI:EU:C:2013:107

4 Council Framework Decision 2009/299/JHA of 26 February 2009 amending Framework Decisions 2002/584/JHA, 2005/214/JHA, 2006/783/JHA, 2008/909/JHA and 2008/947/JHA, thereby enhancing the procedural rights of persons and fostering the application of the principle of mutual recognition to decisions rendered in the absence of the person concerned at the trial [2009] OJ L 81/24

5 Council Framework Decision 2002/584/JHA of 13 June 2002 on the European arrest warrant and the surrender procedures between Member States - Statements made by certain Member States on the adoption of the Framework Decision [2002] OJ L 190/1

6 Council Framework Decision 2002/548/JHA, as amended by Council Framework Decision 2009/299/ JHA, article $4 \mathrm{a}$

Stefano Melloni v. Ministerio Fiscal, par. 14 
a surrender to a country in which he would not be able to challenge a conviction rendered in absentia. ${ }^{8}$

The Spanish Constitutional Court articulated its reference in the form of three questions. ${ }^{9}$ The third one turned out to be of utmost significance for interpreting the systemic protection of human rights within the EU:

"...does Article 53 of the Charter, interpreted schematically in conjunction with the rights recognised under Articles 47 and 48 of the Charter, allow a Member State to make the surrender of a person convicted in absentia conditional upon the conviction being open to review in the requesting State, thus affording those rights a greater level of protection than that deriving from European Union law, in order to avoid an interpretation which restricts or adversely affects a fundamental right recognised by the constitution of the first-mentioned Member State?"10

The answer the CJEU provided to the cited question was a negative one, supported, most directly, with the following reasoning:

“... allowing a Member State to avail itself of Article 53 of the Charter to make the surrender of a person convicted in absentia conditional upon the conviction being open to review in the issuing Member State, a possibility not provided for under the Framework Decision $2009 / 299$, in order to avoid an adverse effect on the right to a fair trial and the rights of the defence guaranteed by the constitution of the executing Member State ... would undermine the principles of mutual trust and recognition which that decision [the Framework Decision] purports to uphold and would, therefore, comprise the efficacy of that framework decision." 11

The cited finding was based on a general rule of interpretation of Article 53 of the Charter which the Court put forth in the same decision:

"It is true that Article 53 ... confirms that, where an EU legal act calls for national implementing measures, national authorities and courts

\footnotetext{
$8 \quad$ Ibid., par. 15-18

9 The manner in which the three questions were structured and formulated seems to suggest that the Spanish Constitutional Court was in fact aiming to receive a specific set of answers. Such analysis, however, would surpass the scope and focus of this paper.

10 Stefano Melloni v. Ministerio Fiscal, par. 26

11 Ibid., par. 64
} 
remain free to apply national standards of protection of fundamental rights, provided that the level of protection provided for by the Charter, as interpreted by the Court, and the primacy, unity and effectiveness of EU law are not thereby compromised." ${ }^{12}$

In order to support this interpretative rule, the Court invoked the authority of its doctrine of primacy of EU law, by referring to its own case law dating as far back as the judgment in Internationale Handelsgesellschaft of $1970 .{ }^{13}$ In contrast to the judgments it cited - Internationale Handelsgesellschaft and Winner Wetten ${ }^{14}$ - both of which upheld primacy and effectivess of EU law as inviolable, ${ }^{15}$ in this instance the Court added a third element: unity of EU law.

\subsection{Significance of the judgment}

The Spanish Constitutional Court complied with the holding of Melloni, modified its case law on the right to a fair trial, but felt compelled to restate its adherence to the controlimiti doctrine. ${ }^{16}$

Prima facie, Melloni and Internationale Handelsgesellschaft may seem similar. Both judgments gave priority to secondary EU law over basic rights, and structural principles in the case of the latter, enshrined in a national constitution of a Member State. The significance of Melloni is not only based, however, on the substance of the holding, but on the context in which it was rendered. During the forty and so years that separate the two judgments, secondary EU law has grown exponentially and has spread to many areas which were previously insulated from it. In parallel with that growth, rose the pressure on constitutional courts of Member States to protect basic rights under national constitutions from possible infringements by virtue of the sprawling EU secondary law. The holding in Melloni prevented that Article 53 of the Charter be instrumentalized for the articulation of that pressure, and that a dent be made in the scope of the non-codified doctrine of primacy of EU law by virtue of mere interpretation of a (codified) Charter provision.

\footnotetext{
$12 \quad$ Ibid., par. 60

13 Judgment of 17 December 1970, Internationale Handelsgesellschaft mbH v Einfuhr-und Vorratsstelle für Getreide und Futtermittel C-11/70, [1970] ECR 1125, ECLI:EU:C:1970:114

14 Judgment of 8 September 2010, Winner Wetten GmbH v Bürgermeisterin der Stadt Bergheim, C-409/06, [2010] ECR I-8015, ECLI:EU:C:2010:503

15 Internationale Handelsgesellschaft mbH $v$ Einfuhr-und Vorratsstelle für Getreide und Futtermittel, par. 3; Winner Wetten GmbH v Bürgermeisterin der Stadt Bergheim, par. 61

16 Torres Pérez, A., Melloni in Three Acts: From Dialogue to Monologue, European Constitutional Law Review, no. 10, 2014, pp. 319-323
} 
As had been explained by De Witte before the judgment in this case was issued, Article 53 is worded in an ambiguous manner: the wording "in their respective fields of application" ${ }^{17}$, pertaining to the Union law, international law and the Member States constitutions, was not well suited to the actual situation in which a great deal of EU law overlaps with the scope of national laws. ${ }^{18}$ Perhaps this perceived ambiguity may very well be the principal reason why the Court in Melloni developed the doctrine of primacy of EU in such manner that it encompasses the "unity" of EU law. The concept of unity clearly underscores that all EU law provisions, even those subject to transposition to national laws, form a unified body of law which is afforded primacy.

Furthermore, the holding in Melloni was particularly significant since the doctrine may have seemed vulnerable after it remained non-codified in the Lisbon Treaty in spite of the fact that its codification had been included in the failed EU Constitution. ${ }^{19}$

The holding, however, instigated fierce academic debates, in which many experts both supported ${ }^{20}$ and criticized it. ${ }^{21}$ De Visser pointed out to expectations that enforcement of fundamental rights at EU level would have a centralizing effect on EU law, which had beenexpressed by several academics, and offered support to such expectations by pointing out to the example of post-WWII Germany, where the activity of the Federal Constitutional Court had such effect. ${ }^{22}$ Similarly, some authors have made comparisons with the protection of basic constitutional rights at the federal level in the US, ${ }^{23}$ although arguments have also appeared, based on

17 Article 53, the Charter

18 De Witte, B., Tensions in the Multilevel Protection of Fundamental Rights, The Meaning of Article 53 EU Charter, in: Silveira, A.; Canotilho, M.; Madeira Froufe, P. (eds.),Citizenship and Solidarity in the European Union P.I.E. Peter Lang, Bruxelles, Bern, Berlin, Frankfurt am Main, New York, Oxford, Wien, 2013, p. 206

19 Article I-6, Treaty Establishing a Constitution for Europe (Rome)

20 E.g. Appanah, D., Charte des droits fondamentaux de l'Union européenne et Convention européenne des droits de l'homme: entre coherence et legitimation. A propos des arrêts Aklagaren c/Hans Akerberg Fransson et Steffano Melloni c/Ministerio Fiscal rendus par la Cour de justice le 23 février 2013, Revue Générale de Droit International Public (R.G.D.I.P.), no. 2, 2014, pp. 333-356

21 Objections to Melloni mostly centered around the claim that the Court prioritized its interests in the constitutional conflict with Member States' courts over protection of human rights. Besselink, L. F. M., The parameters of constitutional conflict after Melloni, European Current Law, vol. 10, 2014, p. 1169

22 De Visser, M., National Constitutional Courts, the Court of Justice and the Protection of Fundamental Rights in a Post-Charter Landscape, Human Rights Review, vol. 15, no. 1, 2014, p. 45

23 Von Papp, K., A Federal Question Doctrine for EU Fundamental Rights Law: Making Sense of Articles 51 and 53 of the Charter of Fundamental Rights, vol. 43. no. 4, 2018, pp. 526-527 
US doctrines on federalism, claiming that the power of Member States to interpret and enforce basic rights in fact benefits "supranational ends". ${ }^{24}$

The outcome in Melloni seemed negative to some authors because, as articulated by Torres Pérez, it meant that European integration requires lowering of the level of the constitutional rights protection. ${ }^{25}$ Assessing relative weight of arguments put forth in those debates would exceed the aim of this paper by far.

\section{FRANSSON - A BROAD CONCEPT OF "IMPLEMENTATION OF UNION LAW"}

\subsection{The facts of the case and the holding}

On the very same day on which the judgment in Melloni was rendered, a Grand Chamber of the Court rendered a judgment in the case Åklagaren v. Hans Akerberg Fransson. ${ }^{26}$ Marek Safjan was the judge rapporteur in both proceedings. In view of the overall direction and reach of the two holdings, the simultaneity of the judgments and the identity of the rapporteur do not seem as a coincidence.

The crux of the Court's reasoning in this judgment does not seem to lie in consideration of the merits of the case, but instead in its jurisdictional part. The case before the CJEU was initiated by a request for preliminary opinion filed by a court in Sweden, the Harapanda District Court, which was facing the question on whether Mr. Åkerberg Fransson could be convicted pursuant to criminal charges for tax frauds for the same actions for which he had been fined by a tax-administration body, in view of the ne bis in idem rules of the ECHR and the Charter. ${ }^{27}$

The jurisdiction of the Court was disputed by the Swedish, Czech and Danish governments, Ireland, the government of the Netherlands, as well as by the European Commission, all of which based their objections to the Court's jurisdiction upon the claim that neither the tax penalties imposed on Mr Fransson and the criminal proceedings brought against him that had been the subject-matter of the main proceedings arose from implementation of EU law, so that the Swedish

24 Torres Pérez, A., The federalizing force of the EU Charter of Fundamental Rights, International Journal of Constitutional Law, vol. 15, no. 4, 2017, pp. 1090-1091

25 Torres Pérez, A., Constitutional Dialogue on European Arrest Warrant: The Spanish Constitutional Court Knocking on Luxembourg's Door, European Constitutional Law Review, no. 8, 2012, p. 127

26 Judgment of 26 February 2013, Åklagaren v. Hans Åkerberg Fransson C-617/10, [2013] ECR, ECLI:EU:C:2013:105

27 Åklagaren v. Hans Åkerberg Fransson, paragraphs 12-14 
courts were not, in respect of subject proceedings, bound by the Charter, in line with Art. 51(1) of the Charter. ${ }^{28}$

The Court, however, ruled in favor of its jurisdiction. ${ }^{29}$ It found that

"tax penalties and criminal proceedings for tax evasion, such as those to which the defendant in the main proceedings has been or is subject because the information concerning VAT that was provided was false, constitute implementation of Articles 2, 250(1) and 273 of Directive 2006/112/EC... and of Article 325 TFEU and, therefore, of European Union law, for the purposes of Article 51(1) of the Charter." ${ }^{30}$

The twofold basis for considering the proceedings brought against Mr. Fransson as implementation of EU law - the provisions of the Council Directive 2006/112/ EC on the common system of value added $\operatorname{tax}^{31}$ and Article 325 TFEU - was established by the Court in a particularly interesting indirect manner, by way of conduits.

Firstly, the Court noted that "the tax penalties and criminal proceedings to which Mr Åkerberg Fransson has been or is subject are connected in part to breaches of his obligations to declare VAT". ${ }^{32}$

In respect of the Council Directive 2006/112/EC, the Court relied on the duty of loyal cooperation, stipulated in Article 4(3), to pronounce the duty of every Member State to ensure collection of VAT and prevent tax evasion. ${ }^{33}$ In doing so, the Court followed the invocation of the duty of loyal cooperation in another judgment, in which it assessed whether Italy had honored its duty to harmonize its laws with an earlier directive introducing VAT. ${ }^{34}$ The conduit for connecting the proceedings against Mr. Fransson in the case at hand and the obligation of Member States to counter illegal activities affecting the financial interests of the European Union, by taking the same measures they take to counter fraud their own

\footnotetext{
28 Ibid., par. 16

$29 \quad$ Ibid., par 31

$30 \quad$ Ibid., par. 27

31 Council Directive 2006/112/EC of 28 November 2006 on the Common System of Value Added Tax, [2006] OJ L 347/1

32 Åklagaren v. Hans Åkerberg Fransson, par. 24

33 Ibid., par. 25

34 Judgment of 17 July 2008, Commission v. Italian Republic C-132/06, [2008] ECR I-5457, ECLI:EU:C:2008:412
} 
interests, as stipulated in Article 325 TFEU, was the inference of the Court that any diminution of VAT revenues of a Member State affects the Union's budget. ${ }^{35}$

The Court proceeded by attempting to articulate elements of a more general rule, and, at the same, to establish a bridge between the two tenets of its finding:

"The fact that the national legislation upon which those tax penalties and criminal proceedings are founded has not been adopted to transpose Directive 2006/112 cannot call that conclusion [that tax penalties and criminal proceedings for tax evasion constitute implementation of EU law] into question, since its application is designed to penalise an infringement of that directive and is therefore intended to implement the obligation imposed on the Member States by the Treaty to impose effective penalties for conduct prejudicial to the financial interests of the European Union." ${ }^{36}$

It should be noted that Advocate General Cruz Villalón had argued against the existence of jurisdiction of the CJEU in this case. In a lengthy reasoning, to which he devoted approximately one third of the entire opinion, he attempted to draw a comprehensive theory of what should be regarded as "scope" and/or "implementation" of EU law. ${ }^{37}$ In order to grasp the order of magnitude of the length to which the Court went in broadening the meaning of "implementation of Union law" in the judgment, one may contrast the Court's holding to some of the concluding points of Cruz Villalón's argument on jurisdiction:

"...It must be recalled that the premiss for finding that the Union has an interest in assuming responsibility for guaranteeing the fundamental right concerned in this case is the degree of connection between Union law, which is in principle being 'implemented', and the exercise of the public authority of the State. In my opinion, that connection is extremely weak and is not, in any event, a sufficient basis for a clearly identifiable interest on the part of the Union in assuming responsibility for guaranteeing that specific fundamental right vis-à-vis the Union." 38

"...the provision of false information to the tax authorities by taxable persons is punished in a general way, as an essential prerequisite

35 Åklagaren v. Hans Åkerberg Fransson, par. 26

36 Ibid., par. 28

37 Opinion of Advocate General Cruz Villalón, of 12 June 2012, C-617/10 Åklagaren v. Hans Åkerberg Fransson, ECLI:EU:C:2012:340, par. 22-65

38 Ibid., par. 57 
of that system of penalties. It is that part of the Swedish tax system which is used for the purposes of collecting VAT." ${ }^{39}$

"In those terms, the question is whether a State legislative activity based directly on Union law is equivalent to the situation in this case, where national law is used to secure objectives laid down in Union law..." 40

"... the structure of the Swedish law on penalties which is, as such, completely independent from the collection of VAT,..." ${ }^{11}$

"... it appears to be risky to assert that, by means of a provision such as Article 273 of Directive 2006/112, the legislature was anticipating the transfer of all the constitutional guarantees governing the exercise of the Member States' power to impose penalties - including the collection of VAT - from the Member States to the Union." ${ }^{42}$

\subsection{Significance of the judgment}

It would be obvious, even to an uninformed reader, that the Court in Fransson afforded an exceptionally broad meaning to the concept of "implementation of Union law," and thus, in effect, broadened the scope of Union law. Such action met numerous and loud protests. Perhaps the reaction of the German Bundessverfassungsgericht represented the most paradigmatic articulation of such opposition. Already in April 2013, the German Constitutional Court rendered a judgment in which it assessed whether the German Counter-Terrorism Database Act infringed upon fundamental rights guaranteed by the German Constitution and the Charter. ${ }^{43}$ That court explicitly referred to Fransson by using rather harsh attributes to describe the nexus to Union law established in that judgment, and threatened to resort to its ultra vires doctrine in case that reasoning in Fransson is applied at its face value:

"The ECJ's decision in the case Åkerberg Fransson ... does not change this conclusion. ..., this decision must not be read in a way that would view it as an apparent ultra vires act or as if it endan-

\footnotetext{
$39 \quad$ Ibid., par 59

40 Ibid., par. 60

$41 \quad$ Ibid., par. 61

42 Ibid., par. 63

43 BVerfG, Judgment of the First Senate of 24 April 2013 - 1 BvR 1215/07, par. 1-233, ECLI:DE:BVerfG:2013:rs20130424.1bvr121507
} 
gered the protection and enforcement of the fundamental rights in the Member States .... The decision must thus not be understood and applied in such a way that absolutely any connection of a provision's subject-matter to the merely abstract scope of Union law, or merely incidental effects on Union law, would be sufficient for binding the Member States by the Union's fundamental rights..." ${ }^{44}$

As pointed out by Torres Pérez, ${ }^{45}$ the CJEU seemed to relativize its Fransson position when in the following year it rendered a judgment in the case Cruciano Siragusa v Regione Sicilia - Soprintendenza Beni Culturali e Ambientali di Palermo. ${ }^{46}$ In the reasoning on its competence for responding to a request for a preliminary opinion by the Regional Administrative Court for Sicily, the Court included the following wording:

"should be borne in mind that the concept of 'implementing Union law', as referred to in Article 51 of the Charter, requires a certain degree of connection above and beyond the matters covered being closely related or one of those matters having an indirect impact on the other..." ${ }^{47}$

The Court, furthermore, referred to a line of judgments, preceding Fransson, which included the set of criteria for determining "whether national legislation involves the implementation of EU law for purposes of Article 51 of the Charter": ${ }^{48}$

"... whether that legislation is intended to implement a provision of EU law; the nature of that legislation and whether it pursues objectives other than those covered by EU law, even if it is capable of indirectly affecting EU law; and also whether there are specific rules of EU law on the matter or capable of affecting it..."49

Fransson, however, continued to be referred to by the CJEU itself and cited by many legal scholars. ${ }^{50}$ Although in most cases it is not being referred to in con-

\footnotetext{
$44 \quad$ Ibid., par. 91

45 Torres Pérez, op. cit., note 24, p. 1084

46 Judgment of 6 March 2014, Cruciano Siragusa v Regione Sicilia - Soprintendenza Beni Culturali e Ambientali di Palermo C-206/13, [2014] ECR, ECLI:EU:C:2014:126

47 Ibid., par. 24

48 Ibid., par. 25

49 Ibid., par. 25

50 "With the Melloni and Akerberg Fransson decisions, handed down the same day - which is certainly no coincidence - the Court of Justice has greatly contributed to the constitution and the structuring of a European constitutional space for fundamental rights," Ritleng, D., The Contribution of the Court of Justice to the Structuring of the European Space of Fundamental Rights, New Journal of European Crimi-
} 
nection with the manner in which the meaning of "implementation of EU law" was interpreted in it, that part of the holding preserves the potential to influence future law due to the high profile of the entire judgment.

\section{CJEU v. ECTHR}

\subsection{Opinion 2/13: exclusive competence of the CJEU and autonomy of EU law}

The progress of EU accession to the ECHR stalled in December 2014, when the CJEU found the respective draft treaty to be incompatible with EU law. ${ }^{51}$ The CJEU based its ruling on a number of reasons, the common denominator of which may be the claim that the draft agreement, by failing to take into account the specific structure of the EU and the specific nature of EU law, contravened the principle of autonomy of EU law, mostly by undermining the exclusive competence of CJEU in respect of interpretation of EU law.

The Court explicitly relied on Melloni and Fransson when it determined that the draft agreement lacked a provision that would ensure that the powers granted by virtue of the ECHR to the Member States "with respect to the rights recognised by the Charter that correspond to those guaranteed by the ECHR" be limited to the extent "which is necessary to ensure that the level of protection provided for by the Charter and the primacy, unity and effectiveness of EU law are not compromised" ${ }^{52}$ In such circumstances, the EU bodies would be subjected to parallel external control of two separate judicial bodies, which would force them to take into account two different sets of interpretations - those of the CJEU and of the ECtHR. ${ }^{33}$ The CJEU also found that treating the EU and its Member States as independent contracting parties to the ECHR would undermine the obligation of mutual trust between Member States and consequently also the "underlying balance of the EU and the autonomy of EU law." ${ }^{4}$ Furthermore, having regard to the fact that the ECHR would become integral part of EU law, the right of Member States to ask for advisory opinions of the ECtHR, would, in view of the CJEU,

nal Law, vol. 5, issue 4, 2014, p. 507; “... and the related Melloni and Akerberg Fransson jurisprudence, which has become part of the primacy architecture of EU law...", Burchardt, D., Belittling the Primacy of EU Law in Taricco II, Verfassungsblog.de, 7 December 2017, [URL=https://verfassungsblog.de/ belittling-the-primacy-of-eu-law-in-taricco-ii/], accessed 14. April 2020

51 Opinion of the Court 2/13 of 18 December 2014, [2014] ECR, ECLI:EU:C:2014:2454

52 Ibid., par. 189

53 "... any action by the bodies given decision-making powers by the ECHR, as provided for in the agreement envisaged, must not have the effect of binding the EU and its institutions, in the exercise of their internal powers, to a particular interpretation of the rules of EU law..." Ibid., par. 184

54 Ibid., par. 194 
undermine autonomy and effectiveness of the preliminary ruling procedure before the CJEU. ${ }^{55}$

\subsection{Significance of Opinion $2 / 13$}

The Opinion effectively stalled accession of the EU to the ECHR up to the present day. Since it was issued, EU institutions have repeatedly declared their commitment to continuing accession negotiations, as well as to complying with all the objections of the Court. At a meeting of EU institutions and the Council of Europe at the end of 2018 it was stated that "all aspects indicated in Opinion 2/13 have been addressed at expert and Council level." In October 2019, the Commission submitted to the Council written contributions in which it allegedly addressed all the objections raised by the CJEU. ${ }^{56}$ In view of the gravity of objections raised by the CJEU and their firm foundations in the constitutional structure of the EU, it is evident that the outcome of such continued negotiations seems rather distant and doubtful.

Opinion 2/13 represents a crown jewell in the long-standing CJEU case law doctrine on autonomy of EU law. The Court seems to have articulated a synthesis of the different aspects of that doctrine, which it had been developing over the past decades in a number of its judgments - autonomy vis-à-vis Member States and international law, in the areas of human rights and external relations. ${ }^{57}$

The opinion has encountered wide-spread critique, primarily coming from authors who believe that constitutional principles of the EU, such as EU law au-

55 Ibid., par. 199. For a detailed analysis of this aspect of the Opinion see: Petrašević T.; Duić, D., Opinion 2/13 on the EU Accession to the ECHR, in: Vinković, M., (ed.), New Developments in the EU Labour, Equality and Human Rights Law, J. J. Strossmayer University of Osijek Faculty of Law, Osijek, 2015, pp. 261-262

56 Legislative train schedule - Completion of EU accession to the ECHR, European Parliament, [https://www. europarl.europa.eu/legislative-train/theme-area-of-justice-and-fundamental-rights/file-completion-ofeu-accession-to-the-echr], accessed 14. April 2020

57 On different facets of the doctrine of autonomy of EU law see: Lukić, M., Autoritet Suda EU ispred pravne sigurnosti - presuda MOX [Authority of the EU Court of Justice more important than legal security - Mox Plant Judgment], Anali Pravnog fakulteta u Beogradu no. 1, 2013, pp. 223-248; Lukić, M., The Security Council's Targeted Sanctions in the Light of Recent Developments Occurring in the EU Context, in: Malloy, M. P. (ed.), Economic Sanctions, Edward Elgar Publishing 2015, Vol. II, pp. 23950; Lukić, M., How Long Before Bundle of Treaties Becomes Sovereign? A Legal Perspective on the Choices before the EU, South Eastern Europe and the European Union - Legal Aspects, SEE/EU Cluster of Excellence in European and International Law vol. 1, Verlag Alma Mater, Saarbrücken 2015, pp. 127137 
tonomy and mutual trust, must not stand in the way of human rights protection under the ECHR. ${ }^{58}$

\subsection{Holding of Opinion 2/13 applied to BITs: Achmea}

The line of reasoning established in Melloni and Fransson and developed in the Opinion $2 / 13$ has been continued further to an equally important point: by following it in Achmea, the CJEU found intra-EU bilateral investment treaties (BITs) to be incompatible with EU law. ${ }^{59}$ Acting pursuant to a reference for a preliminary ruling from the German Federal Court of Justice, the Grand Chamber had to consider observations received from sixteen governments of EU Member States. Its decision was at odds with the opinion of AG Wathelet.

The starting point of the court's reasoning was the invocation of the fact that the EU law is based on a set of common values shared by Member States, as well as of "the existence of mutual trust of Member States that those values will be recognized", and of the principle of sincere cooperation, which obliged the Member States "to ensure in their respective territories the application of and respect for EU law." "The Grand Chamber referred to the principles of primacy and direct effect in order to describe the EU law as a "structured network of principles, rules and mutually interdependent legal relations binding the EU and its Member States reciprocally and binding its Member States to each other" ${ }^{61}$ It then concluded that the arbitral tribunal, provided in the BIT between Slowak Republic and the Netherlands, "may be called on to interpret or indeed to apply EU law, particularly the provisions concerning the fundamental freedoms...". ${ }^{62}$ According

58 As an example of such opinions, see Douglas-Scott, S., Opinion 2/13 and the 'elephant in the room': A response to Daniel Halberstam, Verfassungsblog.de, 13 March 2015, [https://verfassungsblog.de/opinion-213-and-the-elephant-in-the-room-a-response-to-daniel-halberstam-2/], accessed 14. April 2020. The critiques in connection with the principle of mutual trust are summarized in Lenaerts, K., La vie après l'avis: exploring the principle of mutual (yet not blind) trust, Common Market Law Review, vol. 54, 2017, pp. 806-807. See also Krstić, I.; Čučković, B., EU Accession to the ECHR - Enlarging the Human Rights Protection in Europe, Annals of the Faculty of Law in Belgrade - Belgrade Law Review, no. 2, 2016, pp. 49-78. For an example of the conflicting relationship between the principles of mutual trust, solidarity and human rights protection in the specific area of migration and asylum law see Lukić, M.; Čučković, B., Dublin IV Regulation, the Solidarity Principle and Protection of Human Rights - Step(s) Forward or Backward?, in: Duić, D.; Petrašević, T., (eds.), EU Law in Context - Adjustment to Membership and Challenges of the Enlargement, EU and Comparative Law Issues and Challenges Series, University Josip Juraj Strossmayer, Osijek, 2018, pp. 10-30.

59 Judgment of 6 March 2018, Slowakische Republik v Achmea BV C-284/16, [2018] ECR 158, ECLI:EU:C:2018:158

$60 \quad$ Ibid., par. 34

61 Ibid., par. 33

62 Ibid., par. 42 
to EU treaties, interpretation and application of EU law formed exclusive realm of the CJEU, to which courts of Member States must submit such issues. Since the arbitral tribunal prescribed in the subject BIT is not a court of a Member State, subject BIT provision incompatible with EU law, i.e. "having an adverse effect on the autonomy of EU law." ${ }^{63}$ The decision resulted in a plurilateral treaty, reached by EU Member States on 24 October 2019 and signed by 23 Member States on 5 May 2020, on the termination of intra-EU BITs. ${ }^{64}$

\section{EUROPEAN JUDICIAL DIALOGUE CONTINUES: TARRICO I AND II}

\subsection{Tarrico I: financial interests of the EU prioritized over rights of the accused}

In the so-called Tarrico I case, ${ }^{65}$ a CJEU Grand Chamber dealt with a request for a preliminary ruling from the Tribunale di Cuneo in Italy, pertaining to criminal proceedings against a group of persons accused of participating in a value added tax (VAT) evasion scheme. The question addressed by the CJEU was whether the Italian state, by enacting rules on criminal proceedings which materially limited extension of limitation periods for criminal proceedings, created a de facto impunity for tax offenses, which require lengthy proceedings.

The CJEU energetically prioritized effective fulfilment of the Member States' obligations under primary EU law before rights of the accused pursuant to national rules of criminal procedure.

"A national rule in relation to limitation periods for criminal offences ... which provided ... that the interruption of criminal proceedings concerning serious fraud in relation to value added tax had the effect of extending the limitation period by only a quarter of its initial duration - is liable to have an adverse effect on fulfilment of the Member States' obligations under Article 325(1) and (2) TFEU if that national rule prevents the imposition of effective and dissuasive penalties in a significant number of cases of serious fraud affecting the financial interests of the European Union, or provides for longer limitation periods in respect of cases of fraud affecting the financial

$63 \quad$ Ibid., par. 59

64 EU Member States sign an agreement for the termination of intra-EU bilateral investment treaties, [https:// ec.europa.eu/info/publication/200505-bilateral-investment-treaties-agreement_en], accessed 07. May 2020

65 Judgment of 8 September 2015, Ivo Tarrico and Others C-105/14, ECLI:EU:C:2015:555 
interests of the Member State concerned than in respect of those affecting the financial interests of the European Union, which it is for the national court to verify. The national court must give full effect to Article 325(1) and (2) TFEU, if need be by disapplying the provisions of national law ....66

The Court cautioned that "the national court must ensure that the fundamental rights of the persons concerned are respected." ${ }^{67}$ It specifically addressed the objection, raised by several parties, that the disapplication of the subject national rules would infringe upon the rights of the accused under Art. 49 of the Charter (the principles of legality and proportionality of criminal offences and penalties), and found that there would be no such infringement. ${ }^{68}$

\subsection{Tarrico II: pragmatic deference to national courts}

A year after the judgment in Tarrico I was rendered, the Italian Constitutional Court addressed the CJEU with a request for a preliminary ruling on the basis of questions of constitutionality brought before it by the Corte d'appello di Milano and Corte suprema di cassazione, which pertained to the rule established by the CJEU judgment in Tarrico I. ${ }^{69}$ The Italian Constitutional Court based its questions on its finding that rules on limitation in Italian criminal procedural law possess substantive rather than procedural nature, ${ }^{70}$ and therefore asked the CJEU, inter alia, whether Art. 325(1) should have been interpreted as requiring disapplication of national criminal law rules, under the conditions set forth in Tarrico $I$, "even when there is no sufficiently precise legal basis for such disapplication", i.e. when it is not clear that the person committing the infringement could know that EU law required disapplication of subject rules or when it is not clear what "significant number of cases", as prescribed in the Tarrico I holding may actually mean, and even if such rules form part of substantive criminal law. ${ }^{71}$ The CJEU, however, did point out that the principles of non-retroactivity and legality in criminal law formed part of the constitutional traditions common to the Member States, i.e. general principles of EU law according to Art. 6(3) TEU. By doing so, it ensured that the actual basis for not applying Art. 325(1) TFEU were not only Italian constitutional norms, but also the very principles of EU law.

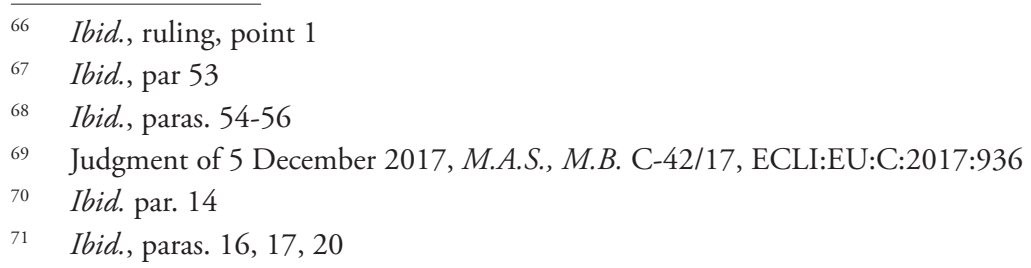


The Grand Chamber in Tarrico II took a deferential course towards the Italian Constitutional Court, since it held that it was up to the national courts to assess whether disapplication of national rules would lead to legal uncertainty, or would breach principles of retroactivity and legality, in which cases the national courts should not disapply subject rules. ${ }^{72}$

\section{EVOLUTION, STAGNATION OR REGRESSION?}

The judgments of the CJEU that have been the subject of the preceding paragraphs are by no means the only judgments that deal with the scope and depth of the fundamental rights' protection within the EU. ${ }^{73}$ They have been selected due to the relative weight they have gained due to subsequent references in CJEU case law, as well as due to the attention paid to them by legal scholars. For these reasons, they have a potential to influence the manner in which EU law and constitutionality are conceived in the future.

In 2013, before the Court rendered the judgments in Melloni and Fransson, De Witte had assessed that the controlimiti doctrine of the Italian Constitutional Court was prevailing, ${ }^{74}$ supposedly among legal academics, but also pointed to the resoluteness of the CJEU not to allow that its doctrine of primacy of EU law concedes even to most fundamental norms of national constitutions. ${ }^{75}$ De Witte saw cases Melloni and Fransson as opportunities for the CJEU to engage national constitutional courts in a "structural dialogue" about interpretation of EU law, citing many EU law experts who had been promoting such dialogue as a solution for the apparent conceptual impasse between these instances. ${ }^{76}$ According to Lenaerts, "the successful operation of the principle of mutual trust and the effective judicial protection of fundamental rights require the national courts, the ECtHR and the ECJ to engage in a constructive dialogue. " 77 As a result of such dialogue, De Visser expressed expectation of occurrence of "substantive convergence and a degree of

$72 \quad$ Ibid., paras. 58-62

73 In particular, we believe that the judgment in Zambrano may have deserved to be included in this review. It presented another bold attempt by the CJEU to promote a wide understanding of the scope of the EU law. The only connection to EU law, on which the CJEU based its competence, in the facts of that case was the EU citizenship of the person(s) involved. Judgment of 8 March 2011, Gerardo Ruiz Zambrano v Office national de l'emploi (ONEm) C-34/09, [2011] ECR I-01177, ECLI:EU:C:2011:124

74 "there is now a general convergence around the position that Union law may prevail ... possibly even over conflicting detailed rules of national constitution, but not over the fundamental provisions of the constitution," De Witte, op. cit,. note 18, pp. 210-211

75 Ibid., p. 211

76 Ibid., p. 211-212

77 Lenaerts, op. cit., note 58 , p. 838 
spontaneous harmonization between the three catalogues of fundamental rights ... - national constitutions, the ECHR and the EU Charter." ${ }^{\text {"78 }}$

CJEU case law analyzed in the preceding sections encompassed intertwining planes of conflicts - between national and EU, as well as between EU and ECtHR law and competence, and, consequently, between individual and EU systemic interests. It may seem naive, from a pragmatically political perspective, to believe that such systemic and far-reaching conflicts may be resolved solely by way of a reasonable dialogue of legal experts.

Protection of fundamental rights belongs to the constitutional law subject matter for the very same reason for which political governance forms part of that matter - it bridges the divide between law and politics, and is most immediately defined by values of the community which purports to protect them. If constitutionality of the EU has indeed been born, it happened due to several decades of CJEU case law on fundamental freedoms and fundamental rights. Protection of fundamental rights is inseparable from EU constitutionality, it forms its very foundation. According to Article $2 \mathrm{TEU}$, respect of human rights is one of the values on which the Union is founded. Preserving the ultimate authority in respect of protection of fundamental rights under EU law for the CJEU is, at this phase of development of $\mathrm{EU}$ constitutionality, its conditio sine qua non. If the EU is based on values, which undisputedly require protection of fundamental rights, then in order to continue to exist, the EU must be able to provide such protection.

The fact that the CJEU in Achmea felt the need to justify its wide-reaching holding on the subject BIT by the necessity to prevent the possibility that the arbitral tribunal may be invoked to interpret... "particularly the provisions of EU law concerning the fundamental freedoms". It seems as though the exclusive authority to interpret EU fundamental freedoms was necessary to affirm the argument in favor of the holding.

The CJEU may not make compromises with the ECtHR simply because, at this stage, it must not make compromises with national constitutional courts, at least in relation to the core principle of primacy of EU law and its authority to interpret EU law. Before the CJEU asserts itself as undisputed authority on rights under the Charter within the EU, it will not be able to make any jurisdictional compromise with the ECtHR.

Centralization of protection of human rights within any given community stems almost instinctively from the universal nature of such rights. If principal civiliza-

78 De Visser, op. cit., note 22, p. 44 
tional, social and political values are shared at the Union level, then the Member States should be comfortable with allowing that such values be articulated through a unified system for protection of human rights. A protection that is provided at multiple levels, resulting from multiple charters, which are coordinated through a "structural dialogue" between courts, ${ }^{79}$ does not seem to offer a stable and longterm solution, and certainly does not seem optimally suited to the universal nature of fundamental rights.

Juxtaposing interests of individuals to EU constitutionality in this context may easily be misleading. In a longer-term perspective, invidiuals' rights will certianly profit if a comprehensive unified system of protection of fundamental rights is established at EU level. With that aim in mind, minor differences between national constitutional charters and the Charter seem negligible.

This does not mean that national constitutions have become irrelevant. The treaties provide mechanisms for continuous transmission of their substance to the EU law: through obligation of the Union to respect national identities of Member States, "inherent in their fundamental structures, political and constitutional," 80 in the form of "constitutional traditions common to Member States, "81 the obligation to interpret fundamental rights under the Charter, "as they result from the constitutional traditions common to the Member States, ... in harmony with those traditions. "82 As Advocate General Bot pointed out in Melloni, Article 4(2) TEU is a norm which preserves the core of a Member States' constitution from infringement, since it provides a basis for a Member State to challenge any act of secondary EU law. ${ }^{83}$

The holdings in Tarrico I and Tarrico II are illustrative of the still ongoing effort on the part of the CJEU to establish all possible aspects of primacy of EU law vis-à-vis legal systems of Member States. Tarrico II seems to be a pragmatic compromise, whereby the CJEU conceded a small aspect of its exclusive authority on EU law to Italian courts for the sake of affirming the general principle of EU law primacy over national constitutional norms.

79 Drenovak-Ivanović, M., The Right to Water and the Right to Use Hydropower: The Case of Serbia and Lessons Learned from the EU, in: Duić, D.; Petrašević, T. (eds.), EU and comparative law issues and challenges series (ECLIC 3), vol. 3, 2019, pp. 214-230

80 Article 4(2), TEU

81 Article 6(3), TEU

82 Article 52(4), the Charter

83 Opinion of Advocate General Bot, of 2 October 2012, C-399/11, Criminal proceedings against Stefano Melloni, ECLI:EU:C:2012:600, par. 138-139 


\section{REFERENCES}

\section{BOOKS AND ARTICLES}

1. Appanah, D., Charte des droits fondamentaux de l'Union européenne et Convention européenne des droits de l'homme: entre coherence et legitimation. A propos des arrêts Aklagaren c/Hans Akerberg Fransson et Steffano Melloni c/Ministerio Fiscal rendus par la Cour de justice le 23 février 2013, Revue Générale de Droit International Public (R.G.D.I.P.), no. 2, 2014, pp. 333-356

2. Besselink, L. F. M., The parameters of constitutional conflict after Melloni, European Current Law, vol. 10, 2014, pp. 1169-1189

3. De Visser, M., National Constitutional Courts, the Court of Justice and the Protection of Fundamental Rights in a Post-Charter Landscape, Human Rights Review, vol. 15, no. 1, 2014, pp. 39-51

4. De Witte, B., Tensions in the Multilevel Protection of Fundamental Rights, The Meaning of Article 53 EU Charter, in: Silveira, A.; Canotilho, M.; Madeira Froufe, P. (eds.), Citizenship and Solidarity in the European Union, P.I.E. Peter Lang, Bruxelles, Bern, Berlin, Frankfurt am Main, New York, Oxford, Wien, 2013, pp. 205-217

5. Drenovak-Ivanović, M., The Right to Water and the Right to Use Hydropower: The Case of Serbia and Lessons Learned from the EU, in: Duić, D.; Petrašević, T. (eds.), EU and comparative law issues and challenges series (ECLIC 3), vol. 3, 2019, pp. 214-230

6. Krstić, I.; Cučković, B., EU Accession to the ECHR - Enlarging the Human Rights Protection in Europe, Annals of the Faculty of Law in Belgrade - Belgrade Law Review, no. 2, 2016, pp. $49-78$

7. Lenaerts, K., La vie après l'avis: exploring the principle of mutual (yet not blind) trust, Common Market Law Review, vol. 54, 2017, pp. 805-840

8. Lukić, M., Autoritet Suda EU ispred pravne sigurnosti - presuda MOX [Authority of the EU Court of Justice more important than legal security - Mox Plant Judgment], Anali Pravnog fakulteta u Beogradu, no. 1, 2013, pp. 223-248

9. Lukić, M., How Long Before Bundle of Treaties Becomes Sovereign? A Legal Perspective on the Choices before the EU, South Eastern Europe and the European Union - Legal Aspects, SEE/ EU Cluster of Excellence in European and International Law vol. 1, Verlag Alma Mater, Saarbrücken 2015, pp. 127-137

10. Lukić, M., The Security Council's Targeted Sanctions in the Light of Recent Developments Occurring in the EU Context, in: Malloy, M. P. (ed.), Economic Sanctions, Edward Elgar Publishing 2015, Vol. II, pp. 239-50

11. Lukić, M.; Čučković, B., Dublin IV Regulation, the Solidarity Principle and Protection of Human Rights - Step(s) Forward or Backward?, in Duić, D.; Petrašević, T., (eds), EU Law in Context - Adjustment to Membership and Challenges of the Enlargement, EU and Comparative Law Issues and Challenges Series, University Josip Juraj Strossmayer, Osijek, 2018, pp. 10-30

12. Petrašević T.; Duić, D., Opinion 2/13 on the EU Accession to the ECHR, in: Vinković, M., (ed.), New Developments in the EU Labour, Equality and Human Rights Law, J. J. Strossmayer University of Osijek Faculty of Law, Osijek, 2015, pp. 251-266 
13. Ritleng, D., The Contribution of the Court of Justice to the Structuring of the European Space of Fundamental Rights, New Journal of European Criminal Law, vol. 5, issue 4, 2014, pp. 507-532

14. Torres Pérez, A., Constitutional Dialogue on European Arrest Warrant: The Spanish Constitutional Court Knocking on Luxembourg's Door, European Constitutional Law Review no. 8, 2012, pp. 105-127

15. Torres Pérez, A., Melloni in Three Acts: From Dialogue to Monologue, European Constitutional Law Review, no. 10, 2014, pp. 308-331

16. Torres Pérez, A., The federalizing force of the EU Charter of Fundamental Rights, International Journal of Constitutional Law, vol. 15, no. 4, 2017, pp. 1080-1097

17. Trstenjak, V.; Beysen, E., The Growing Overlap of Fundamental Freedoms and Fundamental Rights in the Case Law of the CJEU, European Law Review, vol. 38, no. 3, 2013, pp. 293-315

18. Von Papp, K., A Federal Question Doctrine for EU Fundamental Rights Law: Making Sense of Articles 51 and 53 of the Charter of Fundamental Rights, vol. 43. no. 4, 2018, pp. 511-533

19. Weiler, J.H.H, The Reformation of European Constitutionalism, Journal of Common Market Studies Von Papp. 35, issue no. 1, 1997, pp. 97-131

\section{COURT OF JUSTICE OF THE EUROPEAN UNION}

1. Case C-105/14, Ivo Tarrico and Others, ECLI:EU:C:2015:555.

2. Case C-11/70, Internationale Handelsgesellschaft mbH v Einfuhr- und Vorratsstelle für Getreide und Futtermittel [1970] ECR 1125, ECLI:EU:C:1970:114, Judgment of 17 December 1970

3. Case C-132/06, Commission v. Italian Republic [2008] ECR I-5457, ECLI:EU:C:2008:412, Judgment of 17 July 2008

4. Case C-206/13, Cruciano Siragusa v Regione Sicilia - Soprintendenza Beni Culturali e Ambientali di Palermo [2014] ECR, ECLI:EU:C:2014:126 Judgment of 6 March 2014

5. Case C-284/14, Slowakische Republik v Achmea BV [2018] ECR 158, ECLI:EU:C:2018:158

6. Case C-34/09, Gerardo Ruiz Zambrano v Office national de l'emploi (ONEm) [2011] ECR I-01177, ECLI:EU:C:2011:124, Judgment of 8 March 2011

7. Case C-399/11 Stefano Melloni v. Ministerio Fiscal [2013] ECR, ECLI:EU:C:2013:107, Judgment of 26 February 2013

8. Case C-399/11, Criminal proceedings against Stefano Melloni, ECLI:EU:C:2012:600, Opinion of Advocate General Bot, of 2 October 2012

9. Case C-409/06, Winner Wetten GmbH v Bürgermeisterin der Stadt Bergheim [2010] ECR I-8015, ECLI:EU:C:2010:503, Judgment of 8 September 2010

10. Case C-42/17, M.A.S., M.B., ECLI:EU:C:2017:936

11. Case C-617/10, Åklagaren v. Hans Åkerberg Fransson [2013] ECR, ECLI:EU:C:2013:105, Judgment of 26 February 2013

12. Case C-617/10, Åklagaren v. Hans Åkerberg Fransson, ECLI:EU:C:2012:340, Opinion of Advocate General Cruz Villalón, of 12 June 2012 
13. Case Opinion 2/13, Opinion of the Court 2/13 of 18 December 2014, [2014] ECR, ECLI:EU:C:2014:2454

\section{NATIONAL COURTS OF MEMBER STATES}

1. BVerfG, Judgment of the First Senate of 24 April 2013 - 1 BvR 1215/07, par. 1-233, ECLI :DE:BVerfG:2013:rs20130424.1bvr121507

\section{EU LAW}

1. Charter of Fundamental Rights of the European Union [2012] OJ C326/02

2. Council Directive 2006/112/EC of 28 November 2006 on the Common System of Value Added Tax, [2006] OJ L 347/1

3. Council Framework Decision 2002/584/JHA of 13 June 2002 on the European arrest warrant and the surrender procedures between Member States - Statements made by certain Member States on the adoption of the Framework Decision [2002] OJ L 190/1

4. Council Framework Decision 2009/299/JHA of 26 February 2009 amending Framework Decisions 2002/584/JHA, 2005/214/JHA, 2006/783/JHA, 2008/909/JHA and 2008/947/ JHA, thereby enhancing the procedural rights of persons and fostering the application of the principle of mutual recognition to decisions rendered in the absence of the person concerned at the trial [2009] OJ L 81/24

5. Treaty Establishing a Constitution for Europe [2004] OJ C310/1

\section{WEBSITE REFERENCES}

1. Burchardt, D., Belittling the Primacy of EU Law in Taricco II, Verfassungsblog.de, 7 December 2017, [URL=https://verfassungsblog.de/belittling-the-primacy-of-eu-law-in-tariccoii/], accessed 14. April 2020

2. Legislative train schedule - Completion of EU accession to the ECHR, European Parliament, [https://www.europarl.europa.eu/legislative-train/theme-area-of-justice-and-fundamentalrights/file-completion-of-eu-accession-to-the-echr], accessed 14. April 2020

3. EU Member States sign an agreement for the termination of intra-EU bilateral investment treaties, [https://ec.europa.eu/info/publication/200505-bilateral-investment-treaties-agreement_en], accessed 07. May 2020

4. Douglas-Scott, S., Opinion 2/13 and the 'elephant in the room': A response to Daniel Halberstam, Verfassungsblog.de, 13 March 2015, [https://verfassungsblog.de/opinion-213-andthe-elephant-in-the-room-a-response-to-daniel-halberstam-2/], accessed 14. April 2020 